\section{DIGITAL COMMONS \\ @ UNIVERSITY OF SOUTH FLORIDA}

\section{ABO: Interactive Journal for Women in the Arts, 1640-1830}

Volume 9

Issue 2 Fall 2019

Article 7

2019

\title{
A review of Annika Mann, Reading Contagion, by Michael Edson
}

Michael Edson

University of Wyoming, medson@uwyo.edu

Follow this and additional works at: https://digitalcommons.usf.edu/abo

Part of the Dramatic Literature, Criticism and Theory Commons, Educational Methods Commons, Feminist, Gender, and Sexuality Studies Commons, and the Literature in English, British Isles Commons

\section{Recommended Citation}

Edson, Michael (2019) "A review of Annika Mann, Reading Contagion, by Michael Edson," ABO: Interactive Journal for Women in the Arts, 1640-1830: Vol.9: Iss.2, Article 7.

http://doi.org/10.5038/2157-7129.9.2.1225

Available at: https://digitalcommons.usf.edu/abo/vol9/iss2/7

This Reviews is brought to you for free and open access by Digital Commons @ University of South Florida. It has been accepted for inclusion in ABO: Interactive Journal for Women in the Arts, 1640-1830 by an authorized administrator of Digital Commons @ University of South Florida. For more information, please contact digitalcommons@usf.edu. 


\title{
A review of Annika Mann, Reading Contagion, by Michael Edson
}

\author{
Abstract \\ A review of Annika Mann, Reading Contagion, by Michael Edson \\ Creative Commons License \\ (c) (i) (8)
}

This work is licensed under a Creative Commons Attribution-Noncommercial 4.0 License 
Annika Mann. Reading Contagion: The Hazards of Reading in the Age of Print. University of Virginia Press, 2018. xi + 257pp. ISBN: 9780813941776.

Reviewed by Michael Edson

University of Wyoming

That many eighteenth-century writers blamed the increase in print for fanning a fever of reading that endangered youth, women, and servants will be old news for scholars. The ubiquity of the language of disease around books and reading after 1700 may be easily dismissed as part of the metaphorical background noise of the time. In Reading Contagion, Annika Mann considers anew the significance of the contagion imagery in eighteenth- and early nineteenth-century writing about print. For Mann, such language betokens not merely new ideas in medicine enabling a view of reading as "contagious" like disease. Such language in fact marks the arrival of a whole new "theory of reading" that persists, under various guises, into the Victorian age. Per this theory, reading involves "infectious contact with passions and material particulates," contact transforming readers in ways that "cannot be controlled" (3-4). In warning against this contagiousness, Mann argues, writers of the time reveal how texts not only "absorb and transmit contagion as they circulate" among readers but also "create embodied collectives and produce large-scale epidemics" (4). As all this implies, Mann's study focuses especially on those times when textual "contagion" proves no longer merely metaphoric, when figural plague turns material: when books spread real pestilence, when bodies convulse into collective action.

Drawing on recent work in new materialism and posthumanism, Mann reveals "reading contagion" as the flipside of the sentimentalist celebration of passionate identification, of the spread or exchange of passions as healthful to both individuals and the community. As a "counterdiscourse" to this sentimentalist model, reading contagion puts the premise of sentimentalism negatively (13). Books and reading do occasion the involuntary spreading of passions and forming of collectives, but both are dangerous and should be avoided. Mann characterizes reading contagion as "a lastditch" effort by neoclassicists to retain "control over print publication" and as "a rearguard attempt" by cultural conservatives "to reestablish proper social and textual hierarchies" by making reading look hazardous (14). Most basically, Reading Contagion traces this reaction, analyzing writers-Daniel Defoe, Alexander Pope, Tobias Smollett, Edmund Burke, and Samuel Taylor Coleridge - who rejected reading as other than a controlled, bloodless encounter with ideas. What was at stake? To acknowledge reading to involve somatic elements undermining of individual agency challenged the Enlightenment dichotomies of "human and nonhuman, nature and culture, subject and object, mind and body" (8).

As Mann points out, misfortune again and again besets those writers who would educate their readers about the hazards of reading. Such writers inevitably expose the contagious nature of all reading even as they claim that some reading and books (including their own) rise above contagion. Mann's first chapter, "Reading Contagion in Eighteenth-Century Medicine," which traces a shifting view of disease in the medical works of Peter Cheyne and Richard Mead as brought by airborne corpuscles, ends by analyzing Defoe's Journal of the Plague Year (1722). In pointing out the potential contamination carried by books, Defoe's narrator, H. F., implicates his own text in the infection, and though the Journal attempts to excerpt and sanitize previous medical texts that 
spread disease or panic about disease, he still reveals "reading as transformational contact ... with the passions ... [and] material particulates of others" (50).

Mann's second chapter, "Infection" deals with a similar tension in Alexander Pope's "plague poem," the Dunciad in Four Books (1743). Pope reacts against the enthusiastic models of reading and figuration of John Dennis and Richard Blackmore, for whom poetry "represent[s] the speaker's loss of conscious control in response to stimuli, which causes a similarly involuntary, affective reaction within the reader" (58). In his poem, Pope depicts print culture as plague, one characterized by "the disordered, collective bodies of authors and readers and the printed texts they produce, read, and circulate" (61). Under these conditions, not only does authorial agency dissolve and aesthetic and social hierarchies collapse, but figure turns to matter, a transformation embodied in the "excrescence of commentary" that "threatens to bury to poem" (77). But the same fate befalls Pope that befell Defoe: "Pope cannot cultivate awareness of the contagions that can come from reading and preserve his own poem from disease. He is unable to stem the tide of future textual production" around it (21). "In the attempt to make infection visible, to reverse the sanitization of contagion as a theory of productive affect by returning it to matter," his poem falls into the "same toxic materialization" (54).

The next three chapters trace both the begrudging acceptance in later decades of the inevitability of contagious reading as well as new efforts to minimize this contagion or exempt certain forms or genres of writing from contagiousness. In the third chapter, "Inoculation," Mann considers Smollett's two works, The History and Adventures of an Atom (1769) and The Expedition of Humphrey Clinker (1771). "Engage[d] in a career-long struggle with reading contagion," Smollett, himself a physician, is "beset by worries that print might circulate the contagions of an increasing number of readers" (83). In his works Smollett tries to expose and control "the material and affective hazards of reading" by "incorporat[ing] other media forms"-manuscript letters, prints, reviews. In effect Smollett grants that print "carries but can also refuse other infectious media" (84). In this, like Pope and Defoe, Smollett is forced to "abandon attempts to distinguish between diseased and healthy texts or bodies," settling, ultimately, for inoculation, "for producing less virulent strains of infection" (84). The fourth chapter, "Propagation," features two parts, one devoted to the language of contagion in the French Revolutionary-era writings of Thomas Paine and Edmund Burke, the other to William Blake's The [First] Book of Urizen (1794) and Anna Barbauld's "To a Little Invisible Being" (written 1799). As Mann argues, the rise of vital materialism at century's end led to a resurgence in reading contagion and its metaphors. Both radicals and reactionaries of the 1790s argued that print "propagate[s] the revolutionary passions of their readers" and compels these "individual bodies . . into larger social collectives" (108). Notably, the fourth chapter broaches the shifting politics of reading contagion. No longer merely an idiom embraced by traditionalists fearful of print's effects on social and aesthetic hierarchies, reading contagion was now offered as a potential tool for proponents of popular or mass politics.

The fifth chapter, "Extinction," argues for the global plague in Mary Shelley's The Last Man (1826) as representing "the last gasp of reading contagion" after nineteenth-century sanitation reform had linked infection to certain kinds of people and places, and also after "the aesthetics of living form" promulgated by Coleridge and other Romantics had defined poetry as "transcend[ing] the noxious matter of the present" by "possess[ing] formal features that do not mediate the infections of their current readers." Shelley's novel instead returns readers to the eighteenth- 
century view that "all communication is grounded in material media that become infectious the moment they connect one body to another" as well as to "a world in which literary texts, perhaps particularly the genre of poetry, possess no special curative power: all texts are equally contagious" (23). The novel marks a progressive, final installment of reading contagion. Later, "printed texts are no longer objects to fear when all persons have come into contact with and been transformed by them. Print becomes an all-encompassing, endemic condition" (181). Bottom line: disease doesn't raise the same concerns when everyone is already infected.

As with all the titles appearing lately from the University of Virginia Press, Reading Contagion boasts high-quality production and superb copyediting. Readers will find little to object to in the book's argument, too, but they may question the selection of material. First, why this canonical lineup: Defoe, Pope, Smollett, Blake, Shelley? What other authors, especially women, weren't included and why? Surely "reading contagion" wasn't limited to these famous names, or, if it was, what does it say that the purveyors of the theory overwhelmingly populate the canon? Second, Mann claims reading contagion as collapsing distinctions between literary and non-literary texts. But if this is so, then the mainly "literary" authors at the center of this study seem to contradict the spirit of its subject, which "reserves no special place for literary texts" (4). One might wish this tension had been explored. Third, while Mann argues, “[w] can see Pope's evolving response to ... [reading contagion] in his successive versions" of the Dunciad (53), the analysis focuses mainly on the 1743 version, overlooking most of this evolution. She also perhaps underplays the complexity and flux of the commentary to the Dunciad, repeating a formula ("a footnote explains") throughout the analysis that obscures both the specific version of the poem in which the note considered appears (1729 or 1743) and the identities of the annotator: sometimes Pope, sometimes William Warburton, and sometimes Pope as reported by Warburton (added in the 1751 edition). This is a missed opportunity if part of the argument is that the accumulation of notes represents a contagion that challenges author intention and textual control. Such small quibbles aside, Reading Contagion proves an original, timely study grounded in the latest scholarship. As such, the book will appeal to anyone interested in affect, mediation, and medicine in the Enlightenment and beyond. 